\section{Host Resistance in Pyrus to Fabraea Leaf Spot}

\author{
Richard L. Bell and Tom van der Zwet \\ U.S. Department of Agriculture, Agricultural Research Service, Appalachian \\ Fruit Research Station, 45 Wiltshire Road, Kearneysville, WV 25430-9425
}

\author{
Additional index words. Fabraea maculata, Entomosporium maculatum, Diplocarpon \\ mespili, pear
}

\begin{abstract}
Pear leaf spot, caused by the fungus Fabraea maculata Atk. (anamorph: Entomosporium mespili (DC.) Sacc.) occurs in most areas of the world where pears are grown. Most major cultivars of the european pear, $P$. communis $L$., for which data are available are susceptible. Ratings appearing in the literature are sometimes contradictory. This study evaluated resistance/susceptibility within a diverse collection of Pyrus cultivars and other germplasm in a randomized and replicated nursery plot using quantitative measures of disease incidence and severity. The least susceptible genotypes were the $P$. communis cultivars 'Beurre Fouqueray' and 'Bartlett', the $P$. pyrifolia cultivars 'Imamura Aki', and the $P$. communis $\times P$. ussuriensis hybrid NJ 477643275 .
\end{abstract}

Pearleaf spot, caused by the fungus Fabraea maculata Atk. (anamorph: Entomosporium mespili (DC.) Sacc.) occurs in most areas of the world where pears are grown under warm, humid conditions. Susceptible cultivars are often defoliated by midsummer resulting in weak trees and a reduction in fruit buds. Infected fruits are disfigured, cracked, misshapen, and unmarketable as fresh fruit. In the nursery the disease can be serious, causing defoliation and stunted growth (Anderson, 1956). Most major cultivars of the european pear, $P$. communis L., for which data are available are considered susceptible (Bell, 1991). However, ratings appearing in the literature are sometimes contradictory. Resistance to Fabraea leaf spot has been reported in some cultivars of $P$. communis, notably 'Clapp Favorite', 'Doyenné du Comice', 'MinisterDr. Lucius', 'Louise Bonne d'Avranches' and 'Duchesse d'Angouleme' (Esmarch, 1935; Koch, 1907). However, while Kovalev (1963) listed 'Beurre Diel' and 'Bartlett' as resistant, Esmarch (1935) reported them to be susceptible.

Genotypes of a number of east Asian species, P. ussuriensis Maxim., P. pyrifolia (Burm.) Nak., $P$. calleryana Decne., $P$. fauriei Scheid., and $P$. dimorphophylla Mak., have been reported as resistant (Beck, 1958; Kovalev, 1940; Tukey and Braese, 1934; and Wisker, 1916). Zaleski et al. (1959) reported that seedlings of $P$. caucasia Fed. were more resistant than interspecific hybrids of $P$. salicifolia Pall. or $P$. amygdaliformis Vill. with $P$. communis. A multi-year study of 207 Pyrus genotypes (Bell and van derZwet, 1988) demonstrated variability within and among species and interspecific

\footnotetext{
Received for publication 29 Jan. 2003. Accepted for publication 19 June 2004. We thank John Walter and Wayne Zook for technical assistance. Mention of a trademark, proprietary product, or vendor does not constitute a quarantee or warranty of the product by the USDA and does not imply its approval to the exclusion of other products or vendors that also may be suitable.

${ }^{1}$ Research horticulturist.

${ }^{2}$ Research plant pathologist, retired.
}

hybrids. Pure species or interspecific hybrids involving $P$. calleryana, $P$. pyrifolia and $P$. ussuriensis were generally more resistant than P. communis genotypes. Drain (1954) noted resistance in the $P$. communis $\times P$. pyrifolia hybrids, 'Mooers' and 'Hoskins'. Lombard and Westwood (1987) listed seedlings of $P$. caucasia and $P$. cordata Desv. as moderately tolerant, those of the Circum-Mediterranean species $P$. amygdaliformis, $P$. elaeagrifolia Pall., and $P$. syriaca Boiss., and seedlings and clones of $P$. betulifolia Bunge as having high tolerance, $P$. calleryana seedlings and clones as very tolerant, and $P$. pashia D. Don. as susceptible. In contrast to some of the other studies, Lombard and Westwood (1987) list P. pyrifolia and $P$. ussuriensis as having only low tolerance.

One explanation of the disparity among these studies is that each species is heterogeneous for this trait. Furthermore, all studies thus far reported are based upon epiphytotic infections in nonrandomized orchard plots and have not been corroborated by controlled studwere not possible due to the lack of an in vitro cultural medium suitable for the production of large amounts of inoculum until improvements developed by van der Zwet and Stroo (1985). In addition, the ratings were based upon relatively undefined subjective scales, with the exception of a previous study by Bell and van der Zwet (1988), which used a scale based on a visual estimate of the number of lesions and degree of defoliation.

Effective control of the disease requires frequent applications of fungicides throughout the growing season, especially after periods of rain. Cultivars with resistance would reduce grower costs and potential residues associated with pesticide usage. Reliable evaluation methods are needed, and the use of small nursery plots may be more efficient in terms of space and maintenance requirements than orchard plots. This study sought to evaluate resistance or susceptibility within a diverse collection of Pyrus cultivars and other germplasm in a ies. Studies based upon artificial inoculation randomized and replicated nursery plot using quantitative measures of disease incidence and severity.

\section{Materials and Methods}

Plant material. Thirty-four genotypes of pear (Table 1) were selected to represent a range of susceptibility and genetic diversity, and with the exception of three additions, were selected from genotypes studied previously (Bell and van der Zwet, 1988). Five rows of 'Bartlett' seedling rootstocks were planted in a nursery block at a spacing of about $1.5 \mathrm{~m}$ between rows and $0.6 \mathrm{~m}$ between trees. Two trees of each genotype were produced by budding in late summer in a random order onto two rootstocks in each row, and grown into single leader trees the following spring. Lack of bud take reduced the number of trees produced for some genotypes, leading to incomplete blocks (i.e., rows). However, at least three trees of each genotype, and as many as eight, were used in the study. No fungicides were applied during the study. Jones and Aldwinckle (1990) stated that the primary inoculum consists of ascospores and conidia from overwintering leaves, as well as conidia from twig cankers. Therefore, leaves from infected trees in the orchard were collected during the previous fall and spread uniformly in the nursery in an attempt to provide natural inoculum.

Disease evaluation. During the summer, random leaves were examined to confirm that the symptoms were consistent with Fabraea maculata. In late August, 10 leaves were collected from the apical through the basal portions of each tree. The number of lesions per leaf were counted and the most prominent lesion size was estimated using a numeric scale $(0=$ no lesions; $1=$ pinpoint to small; 2 $=$ medium, about 2 to $3 \mathrm{~mm}$ in diameter; $3=$ large, greater than about $3 \mathrm{~mm}$ in diameter; 4 $=$ coalescing necrotic lesions. Relatively little defoliation was observed in the nursery, and therefore, in contrast to the scoring system utilized previously by Bell and van der Zwet (1988), no data on severity of defoliation were collected. In a few cases, some leaves on a tree had been lost due to defoliation or insect damage and the number of leaves per tree on which data could be collected was reduced. Leaf area was measured using a leaf area meter (LI-COR Biosciences, Lincoln, Neb.), and the number of lesions per square centimeter leaf area was calculated.

Statistical analysis. The linear model was a nested linear model with genotypes treated as fixed effects and trees within genotypes and leaves within trees as random effects. The data were analyzed as a completely randomized design due to the incomplete nature of the blocks (i.e., rows). The residuals were computed using SAS PROC MIXED (Littell et al., 1996) and analyzed for normality using the Shapiro-Wilk test and normal probability plots using SAS PROC UNIVARIATE (SAS Institute, 1990). The distribution of mean number of lesions per tree $(\mathrm{W}=0.81, P<\mathrm{W}=<0.0001)$ was not normal, probably due primarily to kurtosis. The distribution of mean lesions per leaf area 
per tree $(\mathrm{W}=0.59, P<\mathrm{W}=<0.0001)$ were not normal, also due to kurtosis, but the mean lesion size per tree was normally distributed (W $=0.99, P<\mathrm{W}=0.53)$. Variances of number of lesions per leaf per genotype were found to be unequal according to plots of residuals versus genotype means and Bartlett's homogeneity of variance test option in SAS PROC GLM $($ SAS Institute, 1990) $($ chi-square $=169.5, P>$ chi-square $=<0.0001$ ), In addition, Spearman's rank correlation, computed using SAS PROC CORR (SAS Institute, 1990), between residuals and genotype means was highly significant $(r$ $=0.67, P<0.0001)$. Variance of the residuals for number of lesions per leaf area were not equal according to the residual versus mean plots, Spearman's rank correlation $(r=0.65$, $P<0.0001$ ), and Bartlett's test (chi-square = $166.7, P>$ chi-square $=<0.0001$ ). Variance of lesion size residuals were equal according to Bartlett's test (chi-square $=32.0, P>$ chi-square $=$ $<0.41$ ), although the residual versus mean plot was inconclusive, due to the discrete nature of the scores. Data for number of lesions per leaf and lesions per leaf area were log transformed. Analysis indicated improvement in equality of variances and normality.

Analyses of variance was performed using SAS PROC MIXED, with denominator degrees of freedom computed by Satterthwaite's method and differences in least-square means adjusted and tested using the Tukey option (Littell et al., 1996). Pearson's correlation coefficients were computed between genotypic means for number of lesions per leaf, lesion size, and lesions per leaf area. Rank correlations between these variables and the mean and minimum severity scores reported in Bell and van der Zwet (1988) were computed. Rank correlations were computed between the proportion of infected leaves and mean lesion size.

\section{Results and Discussion}

Differences among genotypes were highly significant $(P>\mathrm{F}=0.003$ to 0.0001$)$ for number of lesions, leaf area, number of lesions per unit leaf area, and lesion size. Variance due to differences among individual trees of each genotype was also highly significant $(P>\mathrm{F}=0.0001)$ for each measured variable, indicating the need for adequate replication and randomization. Use of infected leaves distributed in the nursery was apparently not effective in achieving uniform inoculum levels throughout the nursery plot. The frequencies of infected leaves on grafted trees were generally high, indicating a lack of immunity. All leaves of fifteen genotypes had at least one lesion on each leaf, but as many as seven leaves of 'Lincoln' had no lesions, either through escape or resistance. There was no relationship between presence or number of uninfected leaves and other measures of infection. Most noninfected leaves for a genotype were on the same tree (data not shown).

The least susceptible genotypes were the $P$. communis cultivars 'Beurre Fouqueray' and 'Bartlett', the $P$. pyrifolia cultivar 'Imamura Aki', and the P. ussuriensis $\times$ P. pyrifolia hybrid NJ 477643275 (Table 1). The most susceptible genotype, with $>12$ lesions $/ \mathrm{cm}^{2}$ of leaf area, was NY 10353. This genotype developed almost twice the number of lesions per leaf area as the next two most susceptible genotypes, NY 10354 and NY 10355. All three of these are $P$. communis $\times P$. ussuriensis $\mathrm{BC}_{1}$ interspecific hybrids. Severe early season defoliation of NY 10353 has been observed in our unsprayed orchard block.

Mean lesion size was smallest in Illinois 76, putatively an interspecific hybrid of $P$. ussuriensis and $P$. pyrifolia (L. F. Hough, pers. comm.), and NJ 477643275, a seedling of Illinois 76 and 'Pai Li'. Mean lesion size ranged continuously up to 'Pai Li' and 'Pontotoc'. Five of the six genotypes with the lowest numbers of lesions per unit leaf area also had the smallest mean lesion size ratings, suggesting that the mechanism of resistance that affects incidence of infection may also retard lesion development.

There were moderate to high positive correlations between mean number of lesions and lesion size $(r=0.54, p=0.001)$ and with lesions per leaf area $(r=0.79, p=<0.0001)$. There was a moderately small, positive rank correlation ( $r=0.37, p=0.03$ ) between the mean proportion of infected leaves and mean lesion size. These observations suggest that

Table 1. Mean per genotype for number of lesions, lesion size, leaf area, and number of lesions per unit leaf area.

\begin{tabular}{|c|c|c|c|c|c|}
\hline Genotype & Species $^{2}$ & No. leaves & $\begin{array}{l}\text { No. lesions } \\
\text { per leaf }\end{array}$ & $\begin{array}{l}\text { Lesion } \\
\text { size }^{y}\end{array}$ & $\begin{array}{l}\text { No. lesions/ } \\
\mathrm{cm}^{2} \text { leaf area }{ }^{\mathrm{x}}\end{array}$ \\
\hline NJ 477643275 & UP & 10 & $4.7 \mathrm{a}^{\mathrm{w}}$ & $1.4 \mathrm{a}$ & $0.2 \mathrm{a}$ \\
\hline Imamura Aki & $\mathrm{P}$ & 45 & $12.2 \mathrm{a}$ & $1.6 \mathrm{ab}$ & $0.5 \mathrm{a}$ \\
\hline Bartlett & $\mathrm{C}$ & 30 & $7.6 \mathrm{a}$ & $1.6 \mathrm{ab}$ & $0.7 \mathrm{a}$ \\
\hline Beurre Fouqueray & $\mathrm{C}$ & 36 & $9.5 \mathrm{a}$ & $2.1 \mathrm{a}-\mathrm{e}$ & $0.7 \mathrm{a}$ \\
\hline Illinois 76 & UP & 28 & $10.9 \mathrm{a}$ & $1.3 \mathrm{a}$ & $0.8 \mathrm{ab}$ \\
\hline Maxine & $\mathrm{C}$ & 37 & $10.9 \mathrm{a}$ & $1.6 \mathrm{abc}$ & $1.1 \mathrm{abc}$ \\
\hline Japan Golden Russet & $\mathrm{P}$ & 10 & $16.2 \mathrm{a}$ & $2.0 \mathrm{a}-\mathrm{e}$ & $1.2 \mathrm{abc}$ \\
\hline Roi Charles de Wurtemburg & $\mathrm{C}$ & 29 & $13.4 \mathrm{a}$ & $2.6 \mathrm{~b}-\mathrm{e}$ & $1.3 \mathrm{abc}$ \\
\hline Meigetsu & $\mathrm{P}$ & 50 & $37.1 \mathrm{ab}$ & $2.4 \mathrm{a}-\mathrm{e}$ & $1.6 \mathrm{abc}$ \\
\hline Lincoln & $\mathrm{C}$ & 63 & $12.2 \mathrm{a}$ & $1.8 \mathrm{a}-\mathrm{e}$ & $1.8 \mathrm{a}-\mathrm{d}$ \\
\hline NY 10274 & $\mathrm{C}$ & 60 & $22.7 \mathrm{a}$ & $1.9 \mathrm{a}-\mathrm{e}$ & $1.9 \mathrm{a}-\mathrm{d}$ \\
\hline Illinois 5E-18 & $\mathrm{PC}$ & 29 & $23.8 \mathrm{a}$ & $2.4 \mathrm{a}-\mathrm{e}$ & $1.9 \mathrm{a}-\mathrm{d}$ \\
\hline Moonglow & $\mathrm{C}$ & 67 & $21.9 \mathrm{a}$ & $2.6 \mathrm{~b}-\mathrm{e}$ & $2.0 \mathrm{a}-\mathrm{d}$ \\
\hline Ames & $\mathrm{PC}$ & 60 & $23.4 \mathrm{a}$ & $1.9 \mathrm{a}-\mathrm{e}$ & $2.1 \mathrm{a}-\mathrm{d}$ \\
\hline Ba Li Hsiang & $\mathrm{U}$ & 40 & $39.2 \mathrm{ab}$ & $2.3 \mathrm{a}-\mathrm{e}$ & $2.1 \mathrm{a}-\mathrm{d}$ \\
\hline Krylov & $\mathrm{UC}$ & 60 & $19.3 \mathrm{a}$ & $2.4 \mathrm{a}-\mathrm{e}$ & $2.1 \mathrm{a}-\mathrm{d}$ \\
\hline Beierschmidt & $\mathrm{C}$ & 18 & $19.5 \mathrm{a}$ & $2.1 \mathrm{a}-\mathrm{e}$ & $2.2 \mathrm{a}-\mathrm{d}$ \\
\hline NY 10369 & $\mathrm{C}$ & 50 & $24.0 \mathrm{a}$ & $2.0 \mathrm{a}-\mathrm{e}$ & $2.3 \mathrm{a}-\mathrm{d}$ \\
\hline O-46-77 & $\mathrm{UC}$ & 59 & $19.3 \mathrm{a}$ & $2.3 \mathrm{a}-\mathrm{e}$ & $2.3 \mathrm{a}-\mathrm{d}$ \\
\hline China & $\mathrm{P}$ & 20 & $39.2 \mathrm{ab}$ & $2.4 \mathrm{a}-\mathrm{e}$ & $2.3 \mathrm{a}-\mathrm{d}$ \\
\hline Monterrey & $\mathrm{PC}$ & 69 & $44.3 a b c$ & $2.0 \mathrm{a}-\mathrm{e}$ & $2.3 \mathrm{a}-\mathrm{d}$ \\
\hline NJ A2 R29 T83 & UPC & 65 & $15.1 \mathrm{a}$ & $1.7 \mathrm{a}-\mathrm{e}$ & $2.6 \mathrm{a}-\mathrm{d}$ \\
\hline Indiana TH 1-187 & UPC & 40 & $41.3 \mathrm{ab}$ & $2.0 \mathrm{a}-\mathrm{e}$ & $2.6 \mathrm{a}-\mathrm{d}$ \\
\hline Huang Hsiang Sui Li & U & 60 & $56.0 \mathrm{a}-\mathrm{d}$ & $2.8 \mathrm{de}$ & $2.7 \mathrm{a}-\mathrm{d}$ \\
\hline NY 10359 & $\mathrm{UC}$ & 48 & $37.8 \mathrm{ab}$ & $2.2 \mathrm{a}-\mathrm{e}$ & $2.8 \mathrm{a}-\mathrm{d}$ \\
\hline Pontotoc & $\mathrm{PC}$ & 31 & $62.5 \mathrm{a}-\mathrm{d}$ & $2.9 \mathrm{e}$ & $3.6 \mathrm{a}-\mathrm{d}$ \\
\hline Tenn 31S46 & $\mathrm{PC}$ & 38 & $41.1 \mathrm{abc}$ & $2.7 \mathrm{cde}$ & $3.7 \mathrm{a}-\mathrm{d}$ \\
\hline Honeysweet & $\mathrm{C}$ & 30 & $29.7 \mathrm{a}$ & $2.3 \mathrm{a}-\mathrm{e}$ & $4.0 \mathrm{a}-\mathrm{d}$ \\
\hline Tang Li & $\mathrm{U}$ & 33 & $117.3 \mathrm{~d}$ & $2.0 \mathrm{a}-\mathrm{e}$ & $5.0 \mathrm{a}-\mathrm{d}$ \\
\hline NJ 487603004 & UPC & 22 & $111.9 \mathrm{~cd}$ & $2.3 \mathrm{a}-\mathrm{e}$ & $5.4 \mathrm{bcd}$ \\
\hline Pai Li & $\mathrm{U}$ & 30 & $106.0 \mathrm{bcd}$ & $3.0 \mathrm{e}$ & $5.7 \mathrm{~cd}$ \\
\hline NY 10355 & $\mathrm{UC}$ & 27 & $63.5 \mathrm{a}-\mathrm{d}$ & $2.3 \mathrm{a}-\mathrm{e}$ & $6.3 \mathrm{~d}$ \\
\hline NY10354 & UC & 38 & $46.7 \mathrm{a}-\mathrm{d}$ & $2.5 \mathrm{a}-\mathrm{e}$ & $6.5 \mathrm{~d}$ \\
\hline NY 10353 & $\mathrm{UC}$ & 25 & $108.2 \mathrm{bcd}$ & $2.8 \mathrm{de}$ & $12.6 \mathrm{e}$ \\
\hline
\end{tabular}

${ }^{2}$ Species: $\mathrm{C}=P$. communis, $\mathrm{P}=P$. pyrifolia, $\mathrm{U}=P$. ussuriensis. Interspecific hybrids are indicated by appropriate combinations.

${ }^{y}$ Lesion size scale: $0=$ no lesion; $1=$ pinpoint to small; $2=$ medium, about 2 to $3 \mathrm{~mm}$ in diameter; $3=$ large, greater than about $3 \mathrm{~mm}$ in diameter; $4=$ coalescing necrotic lesions.

${ }^{x}$ Leaf area was measured in $\mathrm{cm}^{2}$.

${ }^{\text {w} M e a n ~ s e p a r a t i o n ~ w i t h i n ~ c o l u m n s ~ b y ~ W a l l e r-D u n c a n ~ m u l t i p l e ~ r a n g e ~ t e s t ~}(\mathrm{~K}$ ratio $=100)$. Means within each column followed by the same letters are not significantly different. 
diseased overwintered leaves on the ground could serve as a source of primary inoculum on low growing plants, although shoot lesions would also be an important source of inoculum in taller plants, especially as secondary lesions developed during the growing season. The greater amount of inoculum to be expected on trees containing overwintering bark cankers may account for the generally more severe leaf spot infections observed in our earlier study of mature trees (Bell and van der Zwet, 1988). In that study data was collected later, in mid-September, and the more severe scores in that rating scale took into account percentage of defoliation. These differences in assessment date could also account for the generally more severe infection scores, and may have contributed to differences between the two studies. In spite of these differences, the use of objective measurements rather than subjective scales previously used should improve the usefulness and reliability of data. Collecting data in two or more consecutive years would also improve the utility of nursery screening, given the importance of young shoot and bark lesions as a source of inoculum.

As species groups, the $P$. ussuriensis $\times$ $P$. pyrifolia hybrids and the pure $P$. pyrifolia cultivars were most resistant, with mean numbers of lesions per leaf area of 0.5 and 1.4 , respectively. These species and species hybrids were expected to be resistant, based upon our earlier study (Bell and van der Zwet, 1988). The level of disease observed for Illinois 76 also agrees with observations of Hough (1944), who selected this seedling from his study population. The pure $P$. communis cultivars and $P$. pyrifolia $\times P$. communis hybrids averaged 1.8 and 2.7 lesions per unit leaf area, respectively. The means for the $P$. ussuriensis $\times P$. pyrifolia $\times P$. communis hybrids, $P$. ussuriensis $\times P$. communis, and pure P. ussuriensis were 3.5, 3.9, and 5.4 lesions per unit leaf area, respectively. The higher susceptibility observed in the present study, in contrast to previous cited studies, are probably due to differences in the genotypes studied. The most susceptible NY selections are derived from a single $P$. ussuriensis parent, Illinois 65, crossed with susceptible $P$. communis parents. Our present study did not include many of the cultivars previously reported to be resistant, but the $P$. communis cultivars 'Beurre Fougeray' and 'Bartlett', and to a lesser extent 'Maxine', 'Lincoln', and 'Moonglow', and the P. pyrifolia cultivars, 'Imamura Aki' and 'Japan Golden Russet', were moderately resistant in this study as well as in our previous study (Bell and van der Zwet, 1988). Our results for 'Bartlett' agree more closely with Kovalev (1963) than Esmarch (1935). 'Beurre Fougeray', 'Maxine', and 'Moonglow' combine moderate levels of resistance to Fabraea leaf spot with resistance to fire blight. These cultivars should be particularly useful in breeding new disease resistant pear cultivars.

\section{Literature Cited}

Anderson, H.W. 1956. Diseases of fruit crops. McGraw Hill, New York.

Beck, J. 1958. Search continues for disease resistant pear. Rpt. Lafayette, Ind. 1(3):6-7.

Bell, R.L. 1991. Pears (Pyrus). In: J.N. Moore and J.R. Ballington. (eds). Genetic resources of temperate fruit and nut crops. Acta Horticulturae. vol. 290. chapter 14. Intl. Soc. Hort. Sci., Wageningen.

Bell, R.L. and T. van der Zwet. 1988. Susceptibility of Pyrus germplasm to fabraea leaf spot. Acta Hort. 224:229-236.

Drain, B.D. 1954. Blight resistant pears of today and tomorrow. Trans. Ill. Hort. Soc. 88:125-127.

Esmarch, F. 1935. Little known leaf spots of pears. (in German). Kranke. Pflanze. 12:129-132.

Goldsworthy, M.C. and M.A. Smith. 1938. The comparative importance of leaves and twigs as overwintering infection sources of the pear leaf-blight pathogen, Fabraea maculata. Phyto- pathology 28:574-582

Horie, H. and T. Kobayashi. 1980. Entomosporium leaf spot of Pomoideae, Rosaceae in Japan. II. Parasitism and over-wintering of the fungus. Euro. J. For. Pathol. 10:117-124.

Hough, L.F. 1944. The new pear breeding project. Trans. Ill. Hort. Soc. 78:106-110.

Jones, A.L. and H.S. Aldwinckle (eds.). 1990. Compendium of apple and pear diseases. Amer. Phytopathol. Soci., St. Paul, Minn.

Koch, G. 1907. The resistance of different pear varieties against brown leaf (Stigmatea mespili) and the different paradise types against Septoria lycopersici (in German). Z. Landw. Versuchse. Osterr. 10:759-761.

Kovalev, N.V. 1940. Immunity of fruit trees to fungus diseases (in Russian). C.R. Acad. Sci. U.R.S.S. 27:176-179.

Kovalev, N.V. 1963. Leaf blight of pears (in Russian). Zasc. Rast. Vred. Bolez. 8(11):58. Hort. Abstr. 34:2545 (1964).

Littell, R.C., G.A. Milliken, W.W. Stroup, and R.D. Wolfinger. 1996. SAS system for mixed models. SAS Inst. Inc., Cary, N.C.

Lombard, P.B. and M.N. Westwood. 1987. Pear rootstocks, p. 145-183. In: R.C. Rom and R.F. Carlson (eds.). Rootstocks for fruit crops. John Wiley and Sons, New York.

SAS Institute, Inc. 1990. SAS procedures guide. version 6. 3rd ed. SAS Inst., Inc. Cary, N.C.

Tukey, H.B. and K.D. Braese. 1934. Trials with pear stocks in New York. Proc. Amer. Soc. Hort. Sci. 30:361-364.

van der Zwet, T. and H. F. Stroo. 1985. Effects of cultural conditions on sporulation, germination, and pathogenicity of Entomosporium maculatum. Phytopathology 75:94-97.

Wisker, A.L. 1916. Blight-resistant roots-The first step towards pear blight control. Mon. Bul. Calif. Comm. Hort. 5(2):48-53.

Zalaski, K., J. Wierszyllowski, and Z. Rebandel. 1959. Observations and experiments on leaf blight of pear (Fabraea maculata Atk., Entomosporium maculatum Lev.) and its biology and control in seedlings during nursery production (from 1948 to 1954) (in Polish). Prace Kom. Nauk. Roln. Lesn., Poznan 5(1):46. Plant Brdg. Abstr. 30:723 (1960). 